\title{
Influence of growing sites and physicochemical features on the incidence of lenticel breakdown in 'Gala' and 'Galaxy' apples
}

\author{
Magda Andréia Tessmer a , Beatriz Appezzato-da-Glória a , Lucimara Rogéria Antoniolli ${ }^{\mathrm{b}, *}$ \\ a University of São Paulo, Escola Superior de Agricultura “Luiz de Queiroz”, Department of Biological Sciences C.P. 13418-900 Piracicaba, SP, Brazil \\ b Brazilian Agricultural Research Corporation, Embrapa Grape and Wine, 95700-000, C.P. 130, Bento Gonçalves, RS, Brazil
}

\section{A R T I C L E I N F O}

\section{Article history:}

Received 23 November 2015

Received in revised form 19 April 2016

Accepted 20 April 2016

Available online 28 April 2016

\section{Keywords:}

Malus domestica Borkh

Altitude

Storage disorder

Lenticels

Anatomy

\begin{abstract}
A B S T R A C T
The origin of lenticels during apple fruit development growing in different altitudes, the physicochemical and physiological fruit features at harvest and storage, were studied in order to correlate these aspects to lenticel breakdown. 'Gala' and 'Galaxy' apples were harvested from orchards located at three traditional growing regions in Brazil: Vacaria, RS (971 m a.s.l.), Fraiburgo, SC (1048 m a.s.l.) and São Joaquim, SC ( $1353 \mathrm{~m}$ a.s.l.), during the $2008 / 09$ season. The fruit were kept in cold storage (CS) at $0{ }^{\circ} \mathrm{C}$ and $90 \% \mathrm{RH}$ for up to 120 days or at controlled atmosphere (CA) at $1.5 \% \mathrm{O}_{2}, 2.5 \% \mathrm{CO}_{2}, 0^{\circ} \mathrm{C}$ and $90 \% \mathrm{RH}$ for up to 210 days. Colour index was higher in 'Galaxy' apples and in fruit grown in São Joaquim, where the minimum temperatures were approximately $10^{\circ} \mathrm{C}$. The firmness was reduced at CS and CA, but it remained greater than $40 \mathrm{~N}$ in all the treatments. Acidity, except for 'Galaxy' apples, and sugars were influenced by the climatic conditions of the growing sites. There was no relationship between the lenticels dyeing and the incidence of lenticel breakdown. Contrary to the expectations, higher incidence of the disorder was noticed in 'Gala' apples grown in São Joaquim (SC) at the end of the both types of storage. The lenticel breakdown was featured by symptoms such as concentric depression around the lenticels, cell obliteration of the epidermis and subepidermal layers, with wide spaces formed by cell lysis. The origin of lenticels has no influence on the disorder development. It was not possible to establish a relationship among physicochemical, physiological and anatomical features from distinct growing sites and the predisposition to lenticel breakdown disorder.
\end{abstract}

(C) 2016 Published by Elsevier B.V.

\section{Introduction}

Brazil is the ninth worldwide apple producer and 1.330 million tons were produced in 2012. In the same year, the country imported 57,920 tons of fresh fruit and exported 331,734 tons for fresh consumption and juice (FAOSTAT, 2015). The most produced cultivars belong to 'Gala' and 'Fuji' groups, which represent approximately $60 \%$ and $30 \%$ of the Brazilian production (Petri et al., 2011).

The 'Gala' and 'Fuji' cultivars have been replaced by clones with stronger red colour, because the fruit colour is appreciated by the consumer and because these clones combine colour and appearance with fruit quality. The fruit are available in the consumer market throughout the year due to cold storage in air or in controlled atmosphere.

However, despite the advance in postharvest technologies, physiological disorders have received special attention due to the

\footnotetext{
* Corresponding author.

E-mail addresses: bagloria@usp.br (B. Appezzato-da-Glória), lucimara.antoniolli@embrapa.br (L.R. Antoniolli).
}

significant losses they cause. Lenticel breakdown is one of the physiological disorders affecting stored apples. The disorder is initially featured by the lenticels darkening and, in later stages, by the occurrence of brownish depressions around these structures (Curry, 2003; Morales, 1995).

The occurrence of lenticel breakdown in apples have been recorded in Brazil since 2002 (Antoniolli, 2006; Martins et al., 2013). It has also been recorded in producing countries such as South Africa (Turketti et al., 2012.), the United States (Curry, 2002) and Chile (Lara, 2004), and it leads to losses in fruit commercialization and export.

Many factors have been associated with lenticel breakdown. Generally, they may be grouped as factors that occur before or after the harvest. Factors influencing the disorder before harvest include hot and dry periods, especially when the night temperatures are above $10^{\circ} \mathrm{C}$ during the cell elongation period in fruit development (Moggia et al., 2004), mineral contents (Curry, 2003; Morales, 1995) and, more often, bigger fruit (Morales, 1995) and more red colour development (Moggia et al., 1997). The responses to this problem may be orchard-specific and strong year-to-year variation (Turketti et al., 2012). 
The postharvest factors encompass the delay and long storage periods (Morales, 1995), the use of SmartFresh (Kupferman, 2007), and the loss of pulp firmness (Curry and Kupferman, 2004). In addition to the direct damage, the depression region around the lenticels may enable the entry of pathogens causing rottenness, and significantly worsen the percentage of postharvest losses.

The current study aims to investigate the origin of lenticels during fruit development, as well as the physicochemical and physiological features at harvest and storage of 'Gala' and 'Galaxy' apples from three traditional growing regions in Brazil, in order to correlate them to lenticel breakdown.

\section{Materials and methods}

\subsection{Fruit development}

'Gala' and 'Galaxy' apples were sampled from Vacaria-RS (971 m a.s.l.). Six fruit from each variety were sampled one month after the full bloom (when fruit reached $2 \mathrm{~cm}$ diameter and $2.3 \mathrm{~cm}$ length). The other six stages were sampled every 15 days, until fruit ripening. Anatomical analyses were performed by light microscopy.

\subsection{Postharvest treatments}

'Gala' and 'Galaxy' apples were sampled from three different orchards in Vacaria (RS), Fraiburgo (SC) and São Joaquim (SC), Brazil, located at $971 ; 1048$ and $1353 \mathrm{~m}$ a.s.l., respectively, during the 2008/09 season. The growing areas were selected according to the same variety, rootstock and orchard age in order to make the samples as similar to each other as possible.

Fruit were randomly harvested at the commercial maturity stage from plants approximately $1.8 \mathrm{~m}$ high. Fruit were homogenized according to their sizes and to the absence of damages, and stored at cold storage (CS) at $0^{\circ} \mathrm{C}$ and $90 \% \mathrm{RH}$ or at controlled atmosphere (CA) at $1.5 \% \mathrm{O}_{2}, 2.5 \% \mathrm{CO}_{2}, 0{ }^{\circ} \mathrm{C}$ and $90 \% \mathrm{RH}$.

Groups of 30 fruit were used. Fifteen fruit were subjected to physicochemical analysis and the other 15 fruit to lenticels dyeing test and anatomical analyses. The groups were removed from the CS and CA conditions and evaluated at 30-day intervals after the harvest (day 0), during four months (CS) and seven months (CA). Analyses were performed according to colour, firmness, titratable acidity and soluble solids contents, lenticels dyeing and anatomical features by light and scanning microscope.

\subsection{Temperature data collection}

Temperatures were daily collected from July 2008 to February 2009, from automatic weather stations (Fig. 1).

\subsection{Peel colour and pulp firmness}

The colour was determined by Minolta colorimeter, model (CM$508 \mathrm{~d}$ ), and colour index (CI) was calculated as $\mathrm{CI}=1000 . \mathrm{a} /(\mathrm{L} . \mathrm{b})$. The $\mathrm{a}$ and $\mathrm{b}$ values correspond to $a$ and $b$ chroma values, and $L$ is the luminosity. The greater $\mathrm{CI}$ value indicating a more intense red colour in the fruit (Tezotto-Uliana et al., 2013).

Pulp firmness was determined by a digital penetrometer (TR Fruit Pressure Tester, 53205 model) with 8-mm-diameter flat tip. The results were expressed in Newton $(\mathrm{N})$, as the necessary force to break the pulp of each fruit on the opposite sides of the equatorial area after peel removal.

\subsection{Titratable acidity and soluble solids contents}

The titratable acidity was determined using $10 \mathrm{~g}$ juice sample diluted with $90 \mathrm{~mL}$ distilled water, titrated with $1 \mathrm{~N} \mathrm{NaOH}$ at $\mathrm{pH} 8.1$

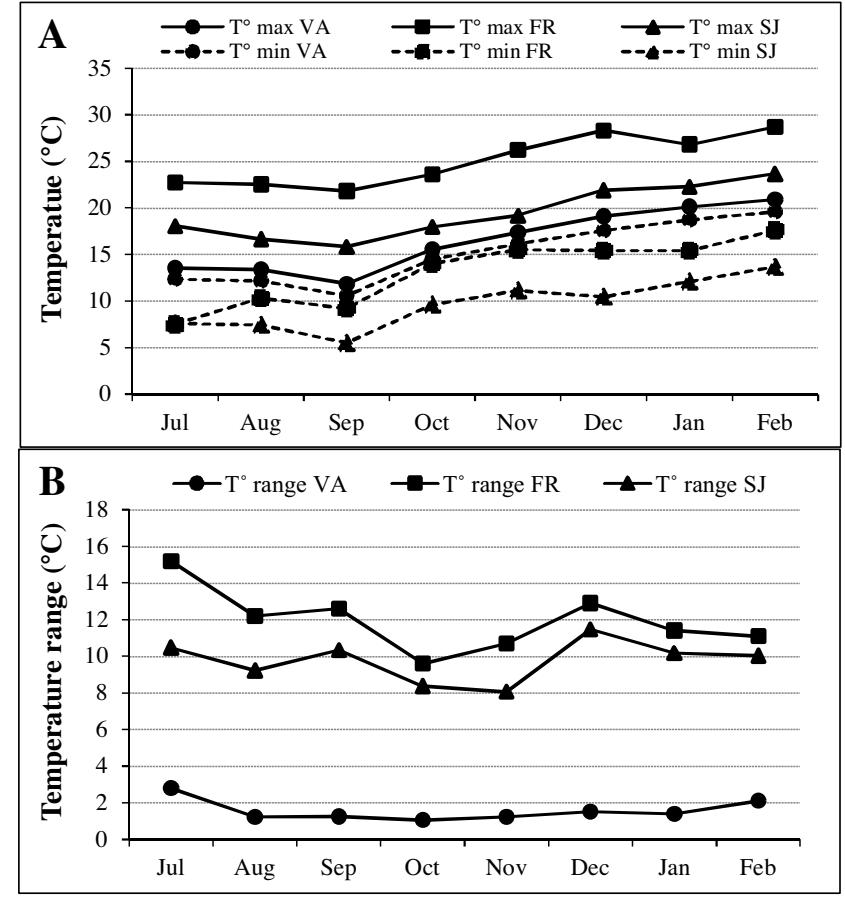

Fig. 1. Monthly average temperatures from the three growing sites located at different altitudes: Vacaria-RS(VA), $971 \mathrm{~m}$; Fraiburgo-SC(FR), $1048 \mathrm{~m}$ and São Joaquim-SC (SJ), $1353 \mathrm{~m}$. (A) Maximum and minimum temperatures and (B) temperature range recorded from July 2008 to February 2009.

and expressed in\% malic acid. The soluble solids content was determined from the pulp homogenized juice by a digital refractometer (ATAGO, model PR-101), with automatic temperature correction at $20^{\circ} \mathrm{C}$. The results were expressed in ${ }^{\circ} \mathrm{Brix}$.

\subsection{Lenticel dyeing test and Lenticel Breakdown measurements}

The lenticels dyeing test was carried out by immersing the fruit in $0.2 \%$ aniline blue solution followed by vacuum infiltration for 30 s according to Curry and Kupferman (2004). The lenticels dyeing severity was ranked in a scale ranging from 1 to $5(1=$ minimal severity; 5 = maximum severity). The results were expressed as percentage (\%) of fruit with lenticels dyeing.

Lenticel Breakdown occurrence was evaluated according to the percentage of fruit affected by the disorder.

\subsection{Light microscopy}

Samples from the equatorial region of 'Gala' and 'Galaxy' fruit during development, after harvest and during storage were removed and immediately fixed in Karnovsky solution (Karnovsky, 1965 ) in a vacuum pump. After fixation, the samples were dehydrated in graded ethanol series and embedded in Leica Historesin ${ }^{\circledR}$ (Heraeus Kulzer, Hanau, Germany) media.

Serial sections ( $5 \mu \mathrm{m}$ thick) were cut on a rotary microtome, stained with toluidine blue (Sakai, 1973) and mounted in Entellan ${ }^{\circledR}$ synthetic resin (Merck, Darmstadt, Germany). The starch grains were detected using zinc-chloride iodine (Strasburger, 1913) and Sudan IV was used to detect lipid substances IV (Pearse, 1968). The images were digitally captured by Leica DMLB microscope (LeicaTM - Wetzlar, Germany) with a video camera connected to a computer. IM50 (LeicaTM - Wetzlar, Germany) software was used for image analysis. 


\subsection{Scanning electron microscopy}

Portions of fruit with lenticels were collected after harvest and during storage and fixed in Karnovsky (Karnovsky, 1965) solution for $24 \mathrm{~h}$. They were then dehydrated in graded ethanol series and subjected to critical point drying with $\mathrm{CO}_{2}$ (Horridge and Tamm, 1969). Regarding to the cryofracture, after the samples were fixed in Karnovsky solution, they were fixed in $30 \%$ glycerin, immersed in liquid nitrogen, fractured by a scalpel, and rinsed with distilled water. Then, the samples were attached to aluminum stubs and coated with gold (30-40 nm). Finally, the samples were examined under LEO VP435 (Zeiss, Oberkochen, Germany) Scanning Electron Microscope at $20 \mathrm{kV}$.

\subsection{Statistical analysis}

The data were subjected to variance analysis (ANOVA) and the sample means were compared to each other by Duncan test $(P \leq 0.05)$ using SASM-Agri statistical package (Canteri et al., 2001).

\section{Results and discussion}

\subsection{Lenticels origin and development in apples}

'Gala' and 'Galaxy' apples from Vacaria-RS showed similar anatomical features during fruit development. At the early stages the uniseriate epidermis undergoes anticlinal cell divisions which promoting its expansion during fruit growth (Fig. 2A). According to Curry (2009), the epidermal cell size is roughly maintained after about 30 days of initial growth in 'Golden Delicious' apple. The fact was also observed in apples 'Gala' and 'Galaxy'.

There are four to six layers of collenchymatic cells, or hypodermis, under the peel. These cells accumulate anthocyanins and phenolic compounds in their vacuoles (Fig. 2A-B). Next, there is the parenchyma with massive isodiametric cells, accumulation of starch grains (Fig. 2B), and collateral vascular bundles (not shown).

The cuticle covers the epidermis and forms flanges between epidermal cells which are present since the beginning of fruit development (Fig. 2C). The thickness of the 'Gala' and 'Galaxy' apples cuticle is influenced by the climate conditions in the growing regions, since cuticle is thicker in higher altitude locations (Tessmer et al., 2012). The cuticle plays an important role against environmental stresses such as wind, solar radiation, dehydration and the entry of fruit-rotting pathogens (Belding et al., 1998).

Non-glandular trichomes are observed in the epidermis in the first and in the second development stages (Fig. 2D). After these stages, it was only possible to see the scar broken-off non-glandular trichome (Fig. 2E). These scars are dispersed among the epidermal cells and they often had microcracks around them. Scars resulting from broken trichomes in the epidermis were also reported for 'Ligol' (Konarska, 2014a) and 'Golden Delicious' apples (Curry, 2009).

Stomata are found on the epidermis of both cultivars during their early development stages (Fig. 2F). These stomata generally occur in substomatic chambers of different sizes and shapes, open or closed (Fig. 2G and H), and they disappear during fruit development due to replacement by lenticels. Konarska (2014b) has found substomatic chambers in the early development of 'Jonagold' apples, and Tetley (1925) reported the absence of stomata in ripe fruit, indicating that lenticels formation should occur in all cases without a trace of stomata.

According to Clements (1935) and Roth (1977), lenticels found in apples may have three different origins: from the stomata that cease functioning in the early fruit development; the epidermal continuity disruption caused by complete removal of trichomes associated with young fruit; and the epidermal disruption resulting from its inability to follow the internal tissue expansion.

The current study found that lenticels were similarly established in the early development stages for 'Gala' and 'Galaxy' apples. Their origin lies on the stomata, in which phellogen invaded the cells lining the substomatal chamber (Fig. $2 \mathrm{H}$ ) and the collenchymatic cells located in discontinuous-peel areas were divided (Fig. 2I) due expansion to the parenchymal cells (Fig. 2J). Lenticels formed from scars caused by trichomes broken were not identified.

According to Webster and Craig (1976), lenticels constitute a layer of large cells with meristematic activity derived from phellogen. The increased number of these cells brings out a certain amount of cells in the organ surface, forming the filling tissue, as seen in the fruit at advanced development stage (Fig. 2K).

Lenticel breakdown disorder such as dimming and depression around the lenticels, were not found in fruit from the early development to the commercial maturity stages. Thus, the relationship between the lenticels origin and the disorder development was not noticed.

\subsection{Influence of growing sites and physicochemical features on lenticel breakdown occurrence}

New apple clones have been largely propagated in recent years due to features such as flavor and stronger red colour of the peel. 'Galaxy' apples had significantly higher colour index than 'Gala' $(P \leq 0.05)$, except for fruit grown in Fraiburgo-SC (Table 1$)$.

Means followed by the same capital letter within the column and by the lower-case letter within the same line are not significantly different from each other by Duncan test $(P \leq 0.05)$.

By comparing the growing sites, it was found that 'Gala' apples showed no difference in colour index, whereas the Galaxy variety from Fraiburgo-SC showed lower colour index (Table 1). São Joaquim is located at the higher altitude, with lower minimum temperatures and Fraiburgo showed higher maximum temperatures during the fruit development cycle (Fig. 1A-B).

The red colour in the apple peel due to anthocyanins and their accumulation is genetically determined as well as by environmental factors such as temperature and light (Gouws and Steyn, 2014; Li et al., 2004; Shü et al., 2001; Curry, 1997). Studies indicate that low temperatures increase whereas higher temperatures reduce the anthocyanins concentration in the apple epidermis ( $\mathrm{Li}$ et al., 2004; Curry, 1997; Faragher, 1983).

The 'Galaxy' apples colour index remained higher during 120 days of storage at both conditions (Fig. 3A). According to Tessmer et al. (2012), colour changes during storage are related to the senescence process and to changes in the cuticle and epicuticular waxes, which were most evident in 'Gala' and 'Galaxy' apples packed at controlled atmosphere.

According to Moggia et al. (1997), red colour apple cultivars are more susceptible to lenticel breakdown. The current study found no correlation between colour and predisposition to the disorder since the 'Gala' apples, which obtained the highest lenticel breakdown percentage, showed lower colour index than the Galaxy variety.

Curry (2002) and Curry and Kupferman (2004) reports that the depressions found around the lenticels in the later lenticel breakdown stages may be related to firmness loss. 'Gala' and 'Galaxy' apples from Vacaria, Fraiburgo and São Joaquim had high firmnessvalues at harvest $(65.02,60.63$ and $78.58 \mathrm{~N})$ and $(74.05,66.61$ and $83.46 \mathrm{~N}$ ), respectively (Table 1 ). As for the growing sites, both cultivars grown in São Joaquim had fruit with higher pulp firmness than those grown in other regions $(P \leq 0.05)$.

During the storage period at CS and CA conditions, there was significant firmness reduction in the fruit from both cultivars in the three growing sites $(P \leq 0.05)$; however, firmness remained above 

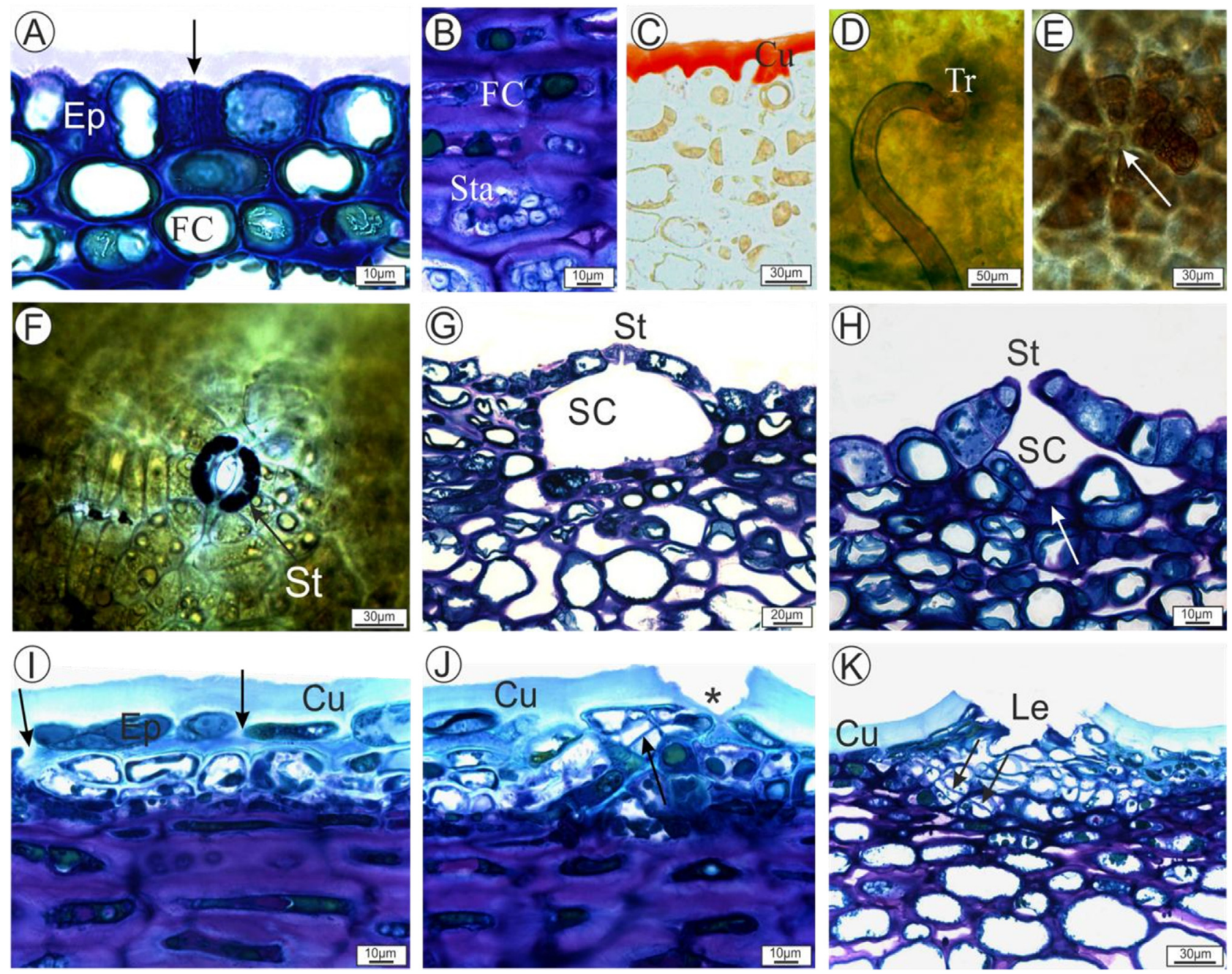

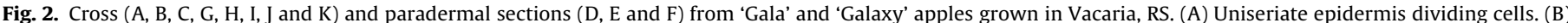

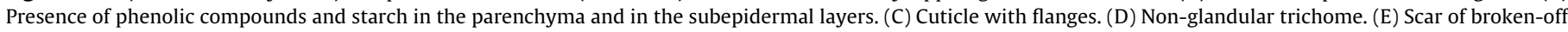

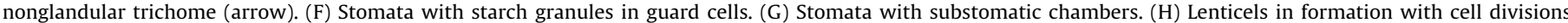

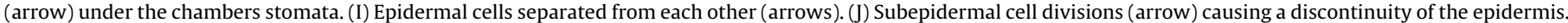

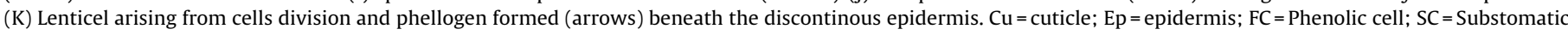
chamber; Sta $=$ Starch; $\mathrm{St}=$ Stomata $\mathbf{T r}=$ Trichome

Table 1

Physicochemical features of 'Gala' and 'Galaxy' apples from three growing sites.

\begin{tabular}{|c|c|c|c|c|c|c|c|c|}
\hline & \multicolumn{8}{|c|}{ Physicochemical features } \\
\hline & \multicolumn{2}{|c|}{ Colour index $(\mathrm{CI})$} & \multicolumn{2}{|c|}{ Firmness $(\mathrm{N})$} & \multicolumn{2}{|c|}{ Titratable acidity (\%) } & \multicolumn{2}{|c|}{ Soluble solids (\%) } \\
\hline & 'Gala' & 'Galaxy' & 'Gala' & 'Galaxy’ & ‘Gala' & ‘Galaxy’ & 'Gala' & 'Galaxy' \\
\hline Vacaria & $37.51 \mathrm{Aa}$ & $55.72 \mathrm{Ab}$ & $65.02 \mathrm{Bb}$ & $74.05 \mathrm{Ba}$ & $0.40 \mathrm{Ba}$ & $0.44 \mathrm{Aa}$ & $13.42 \mathrm{Ab}$ & $14.53 \mathrm{Aa}$ \\
\hline Fraiburgo & $35.26 \mathrm{Aa}$ & $49.87 \mathrm{Ba}$ & $60.63 \mathrm{Ba}$ & $66.61 \mathrm{Ba}$ & $0.27 \mathrm{Cb}$ & $0.50 \mathrm{Aa}$ & $13.13 \mathrm{Bb}$ & $13.55 \mathrm{Ba}$ \\
\hline São Joaquim & $44.32 \mathrm{Aa}$ & $63.55 \mathrm{Ab}$ & $78.58 \mathrm{Aa}$ & $83.46 \mathrm{Aa}$ & $0.47 \mathrm{Aa}$ & $0.49 \mathrm{Aa}$ & $12.67 \mathrm{Ca}$ & $12.72 \mathrm{Ca}$ \\
\hline
\end{tabular}

the threshold required for marketing at the end of the period $(40 \mathrm{~N})$ (Fig. 3B).

In addition to firmness, the titratable acidity and the soluble solids contents are important attributes that give quality and taste to apples. The influence of altitude and climatic conditions on the organic acids and soluble solids in fruits are variable (GuerreroChavez et al., 2015; Li et al., 2004; Shü et al., 2001). 'Gala' apples from the three growing areas showed different titratable acidity $(P \leq 0.05)$ at harvest, with higher content in fruit from São Joaquim.

No difference was observed among 'Galaxy' apples from the three growing areas (Table 1). Li et al. (2004) reported differences in malic acid production during the development of 'Starkrimson' and 'Golden Delicious' apples as a result from the weather conditions and altitude of the growing site; however, they found no significant differences when both varieties were grown in the same environmental condition.

Apples from both cultivars grown in the three growing sites showed reduction $(P \leq 0.05)$ in the acid content during storage at CS and CA conditions. 'Gala' apples grown in Fraiburgo showed lower acidity values (Fig. 4A). Acidity, which is predominantly represented by malic acid gradually decreases during the fruit ripening and storage, which can be explained by the oxidation of acids to obtain energy in the Krebs cycle (Ballod, 1990). 

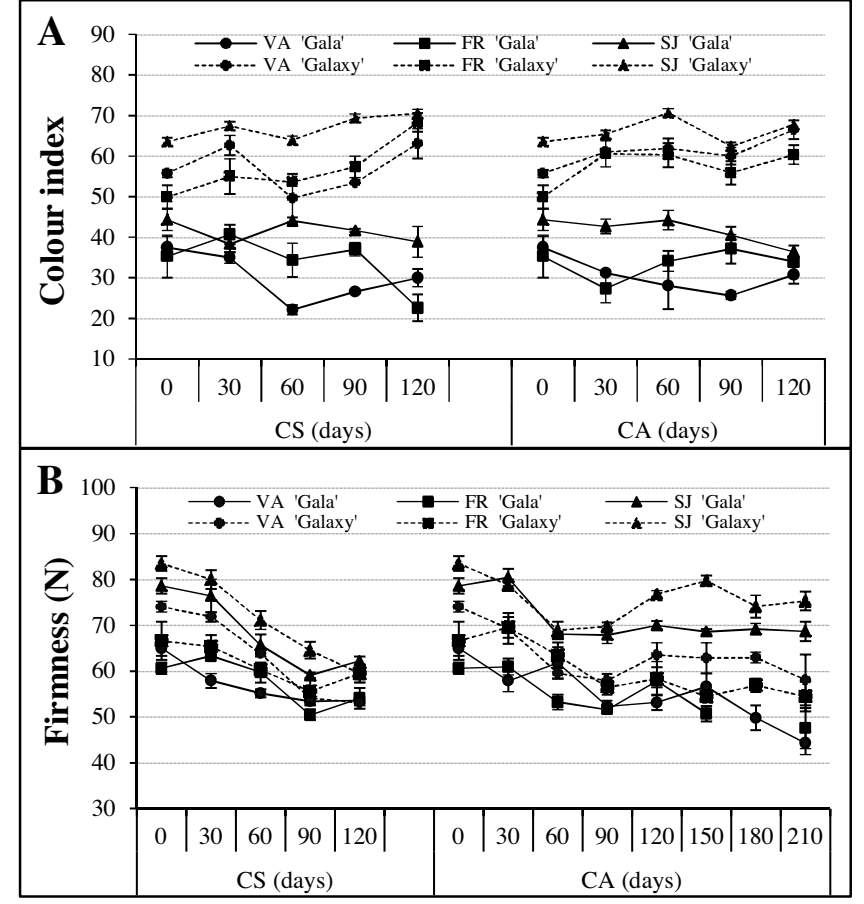

Fig. 3. Colour index (A) and pulp firmness (B) of 'Gala' and 'Galaxy' apples from three growing sites: Vacaria $=$ VA, Fraiburgo $=F R$ and São Joaquim $=S$ J, kept at CS and CA for up to 120 and 210 days, respectively. Vertical bars represent the standard error $(n=4)$.
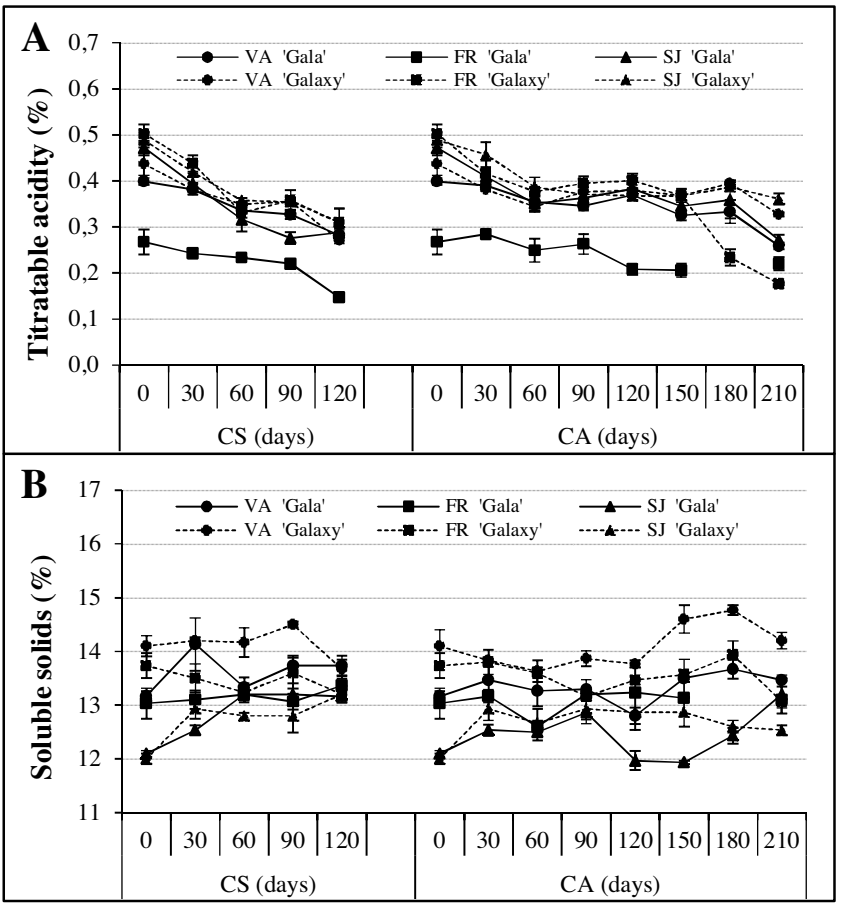

Fig. 4. Titratable acidity (A) and soluble solids (B) contents of 'Gala' and 'Galaxy' apples from three growing sites: Vacaria $=$ VA, Fraiburgo $=F R$, and São Joaquim $=S J$, kept at CS and CA for up to 120 and 210 days, respectively. Vertical bars represent the standard error $(n=4)$.

The soluble solids content from both cultivars was influenced by the weather conditions in the growing sites, since 'Gala' and 'Galaxy' apples grown in Vacaria showed higher soluble solids content and those grown in São Joaquim showed lower soluble solids contents at harvest $(P \leq 0.05)$ (Table 1$)$. Li et al. (2004) attributed the
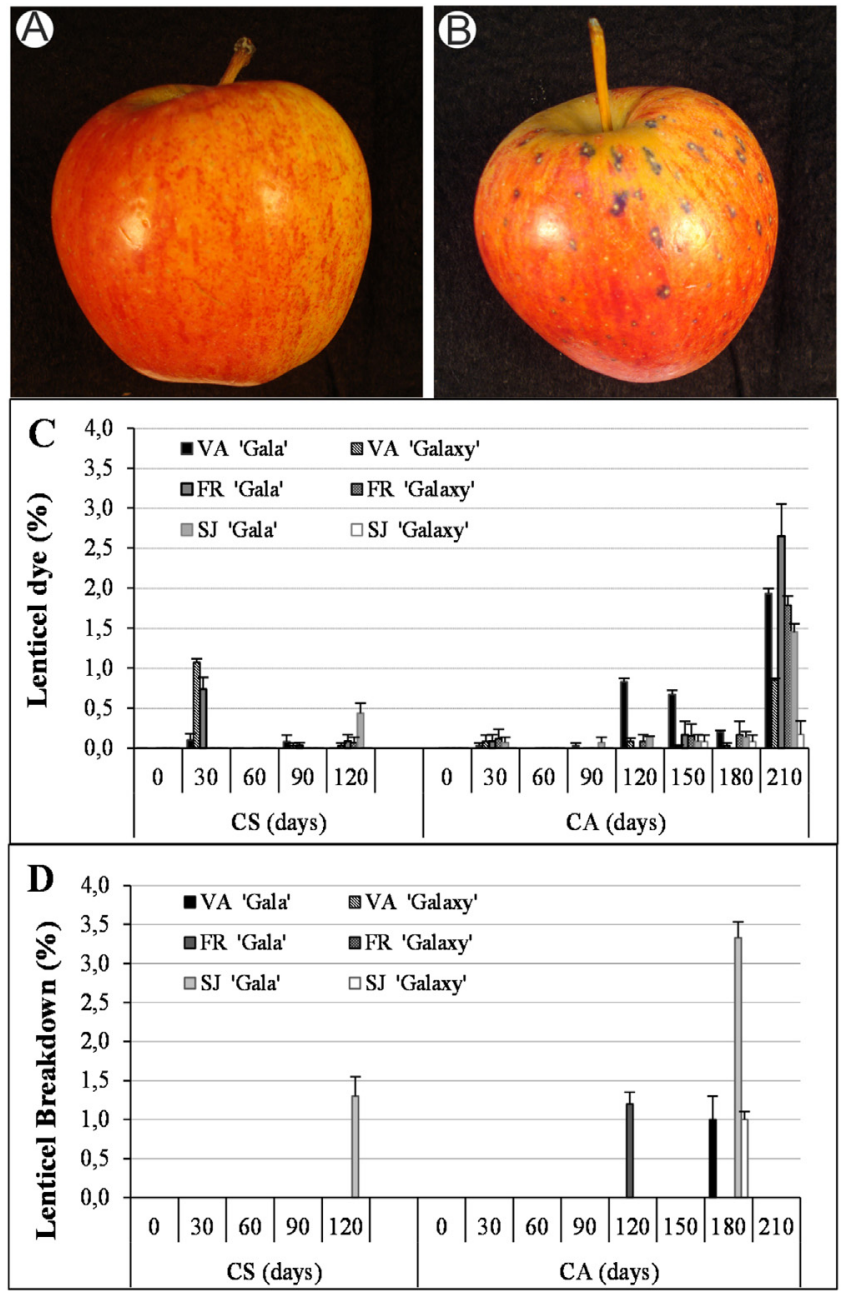

Fig. 5. 'Gala' apples with no dyed lenticels (A), 'Gala' scored 1 (B), dyeing lenticels (C) and lenticel breakdown (D) in fruit from three growing sites: VA=Vacaria, Fraiburgo $=$ FR and São Joaquim $=$ SJ; kept at CS and CA for up to 120 and 210 days, respectively. Vertical bars represent the standard error $(n=4)$.

increase in reducing and non reducing sugars to the development of 'Starkrimson' and 'Golden Delicious' apples and to the growing site. According to Litlle (1992), fruit show lower soluble solids in years or regions with less sunlight during fruit development or as a consequence from excessive rainfall and high humidity.

During storage at CS and CA conditions, the soluble solids content increased $(P \leq 0.05)$ for all the treatments, except for 'Gala' at CS and CA and for 'Galaxy' from Fraiburgo at CS (Fig. 4B). These two varieties remained stable. However, this attribute has not determined the occurrence of the disorder. Curry et al. (2008) also found no relationship between the sugars in the fruit and lenticel breakdown occurrence. According to Argenta (2002), organic acids consumption rates higher than those of sugars during maturation lead to an increase in the sugar/acidity ratio, with consequent changes in the fruit flavor.

Most physicochemical attributes evaluated at harvest showed there is an influence of climate and altitude conditions on both studied cultivars. There was a low occurrence of the disorder and the fruit physicochemical attributes were not decisive regarding to the incidence of lenticel breakdown disorder during storage.

\subsection{Lenticel breakdown predisposition and incidence}

'Gala' and 'Galaxy' apples from the three growing sites showed no staining after harvest (Fig. 5A). As for the storage at CS condi- 

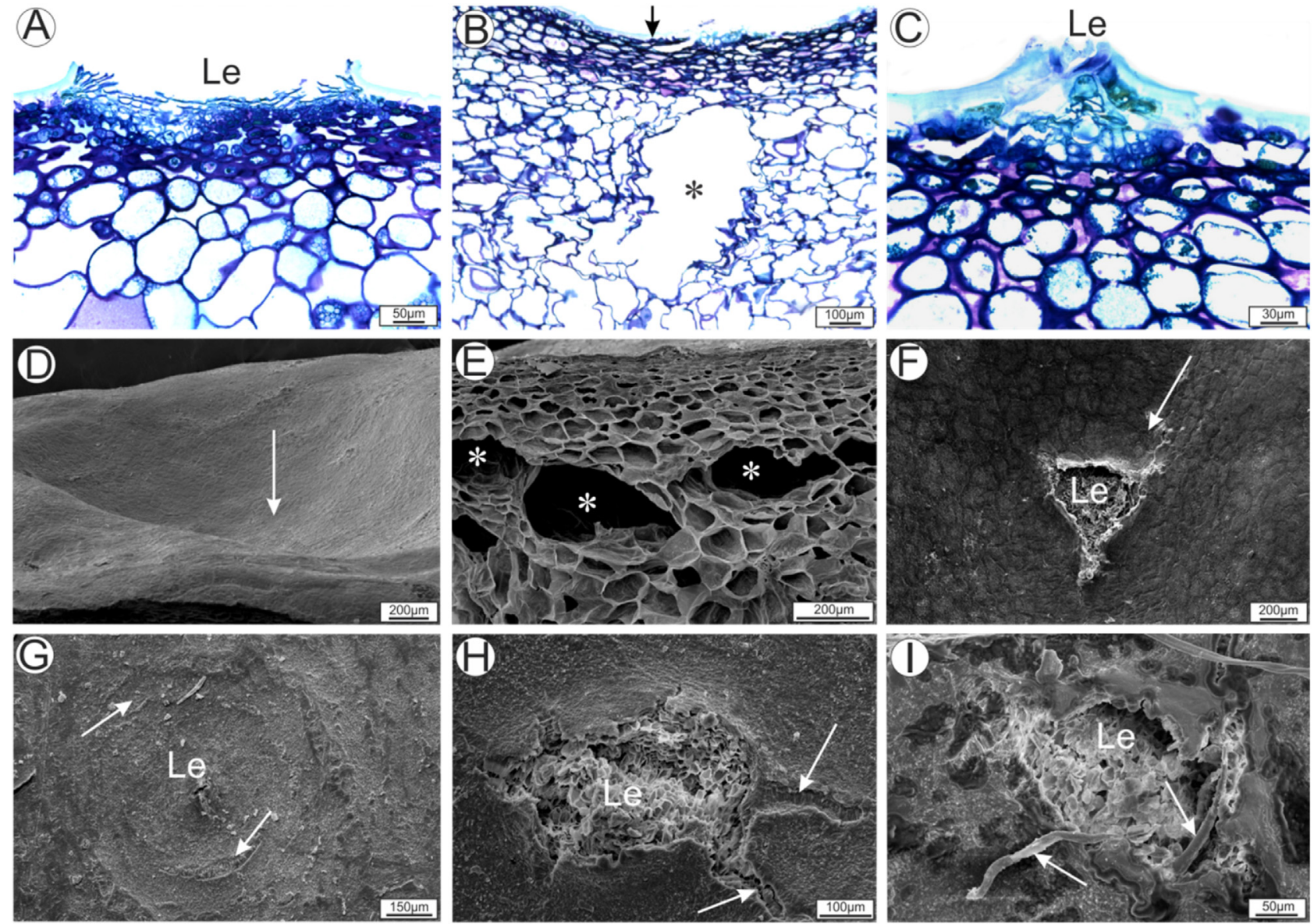

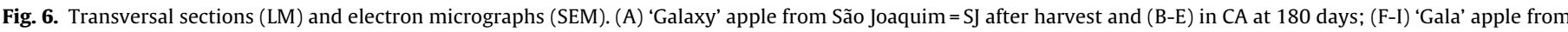

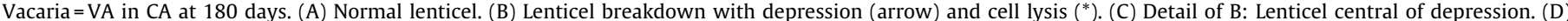

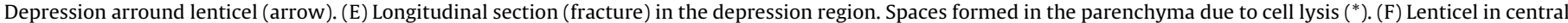
depression. (G) Concentric microcracks around the lenticels in CS storage. (H) Transverse microcracks in lenticels. (I) Fungal penetration in lenticels. Le = Lenticel.

tion, ‘Galaxy’ apples from Vacaria and ‘Gala' apples from Fraiburgo showed $1.1 \%$ and $0.73 \%$ of the sampled fruit with dyed lenticels at 30 days (Fig. 5B-C). Low dyeing percentage was observed during storage and at the end of 120 days. 'Gala' apples from São Joaquim showed $0.43 \%$ of fruit with dyed lenticels. The fruit reached only score 1 throughout the storage period, which indicates minimal dyeing at the severity scale.

Both cultivars at CA storage, except for 'Galaxy' apples from São Joaquim, showed from 0.03 to $0.12 \%$ of the sampled fruit with dyed lenticels at 30 days (Fig. 5C). At 120 and 150 days, 'Gala' apples from Vacaria showed $0.83 \%$ and $0.67 \%$ dyeing, respectively. Greater dyeing percentages were found at the end of 210 storage days, as follows: 'Gala' (1.93\%) and 'Galaxy' (0.85\%) from Vacaria; 'Gala' (2.65\%) and 'Galaxy' (1.78\%) from Fraiburgo; and 'Gala' (1.45\%) and 'Galaxy' (0,17\%) grown in São Joaquim.

The biggest amount of fruit with dyed lenticels at the end of the storage period may due to changes in the cuticle and in the epicuticular waxes (Tessmer et al., 2012), and to the concentric and transverse cracks in the lenticels (Fig. 6G-H) arising from the biosynthetic inability to replace waxes, which allows the penetration of the dye test solution.

The highest incidence of fruit with dyed lenticels occurred in CA. However, the incidence of fruit with lenticel breakdown occurred only in 'Gala' apples (1.2\%) from Fraiburgo at 120 days; in 'Gala' (1.0\%) from Vacaria, and in 'Gala' (3.3\%) and 'Galaxy' (1.0\%) apples from São Joaquim at 180 days (Fig. 5D). Only 'Gala' apples from
São Joaquim expressed $1.3 \%$ lenticel breakdown at 120 days at CS conditions (Fig. 5D). Curry (2001) also found that CA-stored fruit tend to show higher incidence of lenticel breakdown than those kept at cold storage condition.

Curry (2003) reported that lenticel breakdown incidence is influenced by the climatic conditions in the growing site, such as night time temperatures above $10^{\circ} \mathrm{C}$ during the cell elongation period. São Joaquim region has lower minimum temperatures than the other studied locations (Fig. 1A); however, it showed higher percentage of fruit with the disorder. Results indicate that there was low incidence of lenticel breakdown in the 2009 crop and that the lenticels dyeing test was not efficient in indicating the fruit predisposition to lenticel breakdown. These results corroborate those found by Lara (2004), who did not find relationship between lenticels dyeing intensity and the occurrence of lenticel breakdown in 'Royal Gala' apples.

\subsection{Lenticel breakdown anatomical featuring}

The cultivars Gala and Galaxy did not show the lenticel breakdown disorder during fruit development and after harvest (Fig. 6A), and showed low incidence during storage in CS and CA.

The lenticel breakdown symptoms such as concentric depression (Fig. 6B and D) around the lenticels (Fig. 6C and F) were noticed. This depression and cavity results from the obliteration of epidermal and subepidermal cells and from the lysis of parenchyma cells 
(Fig. 6B and E). The cavity associated with lenticel depression were reported in 'Royal Gala' apple (Curry et al., 2008).

Curry et al. (2008) and Curry (2003) observed the lenticels region became darkness due to the development of the depression. The dark colour at that region is probably due to cell compression and drying as observed in Fig. 6B. Histochemical tests to identify compounds (data not shown) revealed no abnormal compound accumulation besides phenols in the subepidermal cells at that region.

The epicuticular waxes had concentric microcracks around the lenticel (Fig. 6G) and arranged transversely to lenticels (Fig. 6H). The microcracks indicate the onset of depression around the lenticels and the expansion - during the storage period - is related to changes in the epicuticular waxes, and probably, the deepening of cell layers. Tessmer et al. (2012) reported that the changes of epicutilar waxes in 'Gala' and 'Galaxy' apples are most evident when fruit are stored in CA.

Differents anatomical changes in lenticelose disorder were not observed between the two cultivars, however, its occurred differences in the number of lenticels with manifestation the disorder. In addition, the penetration of fungus in lenticels cause decay and difficulting the identification of the lenticel breakdown disorder. Konarska (2014a) also observed fungus penetration into the lenticels from ‘Ligol' apples during storage.

\section{Conclusions}

Colour index was higher in 'Galaxy' apples and in both varieties grown in São Joaquim, where the minimum temperatures are approximately $10^{\circ} \mathrm{C}$. The firmness was reduced at CS and CA conditions, but it remained greater than $40 \mathrm{~N}$ in apples from all the treatments. Acidity, except for 'Galaxy', and sugars were influenced by the climatic conditions of the growing sites.

There was no relationship between the lenticels dyeing and the incidence of lenticel breakdown. Contrary to the expectations, higher incidence of the disorder was found in 'Gala' apples grown in São Joaquim-SC at the end of the cold and CA storages.

The lenticel breakdown presented symptoms such as concentric depression around the lenticels, cell obliteration of the epidermis and subepidermal layers, with wide spaces formed by cell lysis. The origin of lenticels has no influence on the disorder development. A relationship among the physicochemical, physiological and anatomical features from the distinct growing sites and the predisposition to lenticel breakdown disorder was not established.

Since the incidence of the disorder in the 2008/09 season was very low, the study should be repeated for several years at distinct growing sites in order to have favourable conditions for the disorder and to make the establishment of the relationship between physicochemical features and incidence of lenticel breakdown possible.

\section{Acknowledgments}

The authors thank Agrofresh and CAPES (Coordenação de Aperfeiçoamento de Pessoal de Ensino Superior) for grants. The authors thank the apple growers from the Southern Brazil, who kindly provided material for this study. This work is part of a Master dissertation of Magda A. Tessmer (Fisiologia e Bioquímica de Plantas, ESALQ Universidade de São Paulo, Brazil).

\section{References}

Antoniolli, L.R., 2006. Lenticelose em Maçãs. Jornal da Fruta 14,1-2 (in Portuguese) Argenta, L.C., 2002. Fisiologia pós-colheita: maturação, colheita e armazenagem dos frutos. In: Argenta, L.C., (Eds.), Manual da cultura da macieira: Florianópolis, pp. 691-732 (in Portuguese).
Ballod, L.B., 1990. Qualidade e potencial de conservação sob atmosfera modificada de pêssegos (Prunus persica (L.) Batsch), cultivares delícia e talismã ESALQ. Lavras, 118 (in Portuguese).

Belding, R.D., Blankenship, S.M., Young, E., Leidy, R.B., 1998. Composition and variability of epicuticular waxes in apple cultivars. J. Am. Soc. Hortic. Sci. 123, 256-348.

Canteri, M.G., Althaus, R.A., Virgens-Filho, J.S., Giglioti, E.A., Godoy, C.V., 2001 SASM-Agri: Sistema para análise e separação de médias em experimentos agrícolas pelos métodos Scoft-Knott, Tukey e Duncan. Rev. Bras. Agroc. 1, 18-24 (in Portuguese).

Clements, H.F., 1935. Morphology and physiology of the pome lenticels of Pyrus malus. Bot. Gaz. 97, 101-117.

Curry, E., 2001. Lenticel and cuticle disorders: a survey. Washington tree fruit postharvest Conference, Proceedings, 1-4. http://postharvest.tfrec.wsu.edu/ proc/PC2001U.pdf.

Curry, E., 2002. Factors Contributing to lenticels Breakdown. Washington tree fruit postharvest Conference, Proceedings, Wenatchee, $1-4$. http://postharvest. tfrec.wsu.edu/proc/PC2002.

Curry, E., 2003. Factors associated with apple lenticel breakdown. Washington Tree Fruit Postharvest Conference, Proceedings, Wenatchee, 1-9. http:// postharvest.tfrec.wsu.edu/REP2003B.pdf.

Curry, E., 2009. Growth-induced microcracking and repair mechanisms of fruit cuticles. In: Proceedings of the SEM Annual Conference, New Mexico, pp. 1-4.

Curry, E., Kupferman, E., 2004. Predicting susceptibility of 'Gala' apples to lenticel breakdown disorder: Guidelines for using the dye uptake test. Washington tree fruit postharvest conference, Proceedings, Wenatchee, 1-7. http:// postharvest.tfrec.wsu.edu/aniline-blue.pdf.

Curry, E., Torres, C., Neubauer, L., 2008. Preharvest lipophilic coatings reduce lenticel Breakdown disorder in 'Gala' apples. HortTechnology 18, 690-696.

Curry, E.A., 1997. Temperatures for optimal anthocyanin accumulation in apple skin. J. Hortic. Sci. 72, 723-729.

FAOSTAT -Food Agricultural Organization Statistical, 2015. Agricultural Data. http://faostat.fao.org/faostat/collections.

Faragher, J.D., 1983. Temperature regulation of anthocyanin accumulation in apple skin. J. Exp. Bot. 34, 1291-1298.

Gouws, A., Steyn, W.J., 2014. The effect of temperature, region and season on red colour development in apple peel under constant irradiance. Sci. Hortic. 173, 79-85.

Guerrero-Chavez, G., Scampicchio, M., Andreotti, C., 2015. Influence of the site altitude on strawberry phenolic composition andquality. Sci. Hortic. 192, $21-28$.

Horridge, G.A., Tamm, S.L., 1969. Critical point drying for scanning electron microscopy study of ciliarmotion. Science $13,818-871$.

Karnovsky, M.J.A., 1965. Formaldehyde-glutaraldehyde fixative of high osmolality for use in electron microscopy. J. Cell Biol. 27, 137-138.

Konarska, A., 2014a. Morphological, histological and ultrastructural changes in fruit epidermis of apple Malus domestica cv Ligol (Rosaceae) at fruit set, maturity and storage. Acta Biol. Cracov. Ser. Bot. 56, 1-14.

Konarska, A., 2014b. Differences in the structure of fruit buds in two apple cultivars with particular emphasis on features responsible for fruit storability and quality. Acta Sci. Pol. Hortorum Cultus 13, 91-105.

Kupferman G. 2007. Plain talk about apple Lenticel Breakdown. Good Fruit Grower Magazine, 58, 1-3. http://postharvest.tfrec.wsu.edu/EMK2007C.pdf.

Lara, C.R.A. 2004. Desarrollo de lenticelosis e manzanas cv. Royal Gala. Facultad de Ciencias Agrárias, Memoria de Titulo, Talca, 1-35 (in Spanish).

Li, X.J., Hou, J.H., Zhang, G.L., Liu, R.S., Yang, Y.G., Hu, Y.X., Lin, J.X., 2004. Comparison of anthocyanin accumulation and morpho-anatomical features in apple skin during color formation at two habitats. Sci. Hortic. 99, 41-53.

Martins, C.R., Hoffmann, A., Rombaldi, C.V., Farias, R.M., Teodoro, A.V., 2013. Apple biological and physiological disorders in the orchard and in postharvest according to production system. Rev. Bras. Frutic. 35, 001-008.

Moggia, C., Yuri, J., Lozano, P., 1997. Problemas lenticelares em manzanas. Revista Frutícola 18, 67-72 (in Spanish)

Moggia, C., Yuri, J.A., Acevedo, C., Pereira, M., 2004. Desarrollo de lenticelosis en manzanas cv. Royal Gala 4, 1-4 (in Spanish) http://pomaceas.utalca.cl.

Morales, A., 1995. Manchas lenticelares en manzanas Gala y Royal Gala. Aconex 47, 15-17 (in Spanish).

Pearse, A.G.E., 1968. Histochemistry, theoretical and applied, vol. 1. Churchill London, pp. 998

Petri, J.L., Leite, G.B., Couto, M., Francescatto, P., 2011. Avanços na cultura da macieira no Brasil. Rev. Bras. Frutic., 048-056 (in Portuguese).

Roth, I., 1977. Fruits of Angiosperms. Gebrüder Borntraeger, Berlin, Stuttgart, pp. 234

Sakai, W.S., 1973. Stain Technol. 48, 247-249 (Baltimor).

Shü, Z.H., Chu, C.C., Hwang, L.J., Shieh, C.S., 2001. Light, temperature, and sucrose affect color diameter, and soluble solids of disks of wax apple fruit skin. Hortic. Sci. 36, 279-281.

Strasburger, E., 1913. Handbook of Practical Botany, 7th ed. George Allen, London, pp. 527.

Tessmer, M.A. Antoniolli, L.R., Appezzato-da-Glória, B., 2012. Cuticle of 'Gala' and 'Galaxy' apples cultivars under different environmental conditions. Braz. Arch. Biol. Technol. 55, 709-714.

Tetley, U., 1925. The secretory system of the roots of the compositae. New Phytol 24, 138-161. 
Tezotto-Uliana, J.V., Berno, N.D., Quispe, F.R.S., Kluge, R.A., 2013. Gamma radiation: an efficient technology to conserve the quality of fresh raspberries. Sci. Hortic. $164,348-352$.

Turketti, S.S., Curry, E., Lötze, E., 2012. Role of lenticel morphology, frequency and density on incidence of Lenticel Breakdown in 'Gala' apples. Sci. Hortic. 138, 90-95.
Webster, B.D., Craig, M.E., 1976. Net morphogenesis and characteristics of the surface of muskmelon fruit. J. Am. Soc. Hortic. Sci. 101, 412-415. 